\title{
EFFECT OF SOCIO-DEMOGRAPHIC FACTORS ON THE CONSISTENCY OF CONDOM USE AMONG FEMALE SEX WORKERS IN TULUNGAGUNG DISTRICT, EAST JAVA
}

\author{
Ainun Hanifa ${ }^{1)}$, Ari Natalia Probandari²), Eti Poncorini Pamungkasari²) \\ 1)Diploma III Program in Midwifery, Tulungagung University \\ ${ }^{2)}$ Faculty of Medicine, Sebelas Maret University
}

\begin{abstract}
Background: Sexually Transmitted Infection (STI) is common among female sex workers (FSW). STI can be cured by correct diagnosis and prompt treatment. Correct treatment depends on the specific causal infection agent, as well as host and environmental factors. This study aimed to examine the effect of socio-demographic factors on the consistency of condom use among female sex workers in Tulungagung district, East Java.

Subjects and Method: This was an analytic and observational study using cohort design. It was conducted at Ngujang and Gunung Bolo prostitution areas, Tulungagung, East Java, from November to December 2017. A total sample of 90 female sex workers was selected for this study. The dependent variable was consistency of condom use. The independent variables were age, marital status, education, urban-rural residence, exposure to information from health personnel. The data were collected by a set of questionnaire and diary. The data were analyzed by chi square and logistic regression model.

Results: Bivariate analysis with chi square test showed that female sex workers working at Ngujang prostitution area $(\mathrm{OR}=11.7 ; 95 \% \mathrm{CI}=11.7$ to 95.9; $\mathrm{p}<0.001)$, widow $(\mathrm{OR}=1.28 ; 95 \% \mathrm{CI}=1.12$ to $1.45 ; \mathrm{p}=0.012)$, education level lower than senior high school $(\mathrm{OR}=1.30 ; 95 \% \mathrm{CI}=1.13$ to $1.49 ; \mathrm{p}=0.005)$, were more likely to use condom consistently than those working at Gunung Bolo, married/ single, education level senior high school or higher, respectively. Female sex workers aged $\geq 35$ years old $(\mathrm{OR}=0.77 ; 95 \% \mathrm{CI}=0.68$ to $0.89 ; \mathrm{p}=0.006)$, rural origin $(\mathrm{OR}=-0.65 ; 95 \% \mathrm{CI}=0.2$ to $2.12 ; \mathrm{p}=0.474)$, receiving health information from health personnel $(\mathrm{OR}=0.79 ; 95 \% \mathrm{CI}=0.70$ to $0.90 ; \mathrm{p}=0.017$ ), were less likely to use condom consistently than aged $<35$ years old, urban origin, not receiving information from health personnel.

Conclusion: Female sex workers working at Ngujang prostitution area, widow, education level less than high school, were more likely to use condom consistently than at Gunung Bolo, married/ single, education level senior high school/higher, respectively.
\end{abstract}

Keywords: sexually transmitted infection, consistent use of condom, sociodemographic factors

Correspondence: Ainun Hanifa. Diploma III Program in Midwifery, Tulungagung University. Email: arfabachtiar13@gmail.com. 